\title{
Effect of level of intake during the milk-feeding period on post-weaning growth in lambs
}

\author{
T. Manso, A.R. Mantecón, P. Lavin, F.J. Giraldez, R. Peláez \\ and F.J. Ovejero
}

Estación Agricola Experimental, CSTC Apdo 788

24080 León. Spain

(Received 2 July 1996; accepted 13 September 1996)

\begin{abstract}
Twenty four Churra lambs from multiple births were assigned to a $3 \times 2$ factorial design, with three levels of milk intake (837- L, 1046-M and $1255-\mathrm{H}$ kJ gross energy per kg metabolic body weight per day) and two sexes (males and females). The effects of these factors on growth rate during the milk-fceding period ( 0 to 30 days), weaning period ( 31 to 37 days) and post-weaning period ( 38 to 77 days) were studied. The live weight gain during the milk-feeding period was statistically differen1 $(P<0.001)$ for the three levels of milk intake $(66,109$ and $127 \mathrm{~g}$ /day). Dry matter, crude protein and gross energy digestibilities of the milk substitute were lower $(\mathrm{P}<0.05)$ for the $\mathrm{H}$ level of intake than the $\mathrm{L}$ and $\mathrm{M}$ levels. Weight losses during the weaning period were inversely related to the pre-weaning levels of milk intake. The live weight gains were not statistically different between malc and fcmalc lambs during cither the pre- or post-weaning periods. Post-weaning daily live weight gains were 34.4, 31.1 and $27.1 \mathrm{~g} / \mathrm{kg}^{0.75}$ for $\mathrm{L}, \mathrm{M}$ and $\mathrm{H}$ levels of milk intake respectively $(\mathrm{P}<0.001)$.
\end{abstract}

KEY WORDS: lamb, growth, milk-fed

\section{INTRODUCTION}

In Spain, the Churra breed is traditionally the most important milking breed of sheep. This breed is early developing and traditionally their lambs are slaughtered during the sucking period, when they are about 25-35 days old and of low body weight (10-12 kg) (Lavin et al., 1994). However, since the Spanish participation in the Europcan Community, new markets are becoming available and there are occasions when early weaning is necessary in order to increase the availability of acceptable lean lambs in the appropiate weight ranges. There is also a need to provide a more even supply of lambs to the market (Lavin et al., 
1994). A strategy for reducing both the cost of feeding and the post-weaning growth check is restricting milk replacer intake during the milk-feeding period (Davies and Owen, 1967; Owen et al., 1969; Walker and Hunt, 1981; Manso et al., 1994). However, this strategy has not been widely adopted because it often results in a high variability in post-weaning performance (Iason et al., 1992). The variability in compensatory growth response suggests that several factors may be involved. One of the most important of these is the age at which the restriction is imposed (O'Donovan, 1984; Ryan, 1990). Although lambs restricted soon after birth are unlikely to show compensatory growth, it has been suggested that the stage, relative to maturity, is more important than the age per sc (Wright et al., 1987; Iason et al., 1992). A comparative study of lambs (Thonney et al., 1987) has shown that females and genotypes of small mature liveweight reach maturity at younger ages.

The present experiment was designed to study the effect of the sex of Churra lambs and level of milk intake on their subsequent intake and growth. The results are of special practical importance in sheep production systems where lambs are reared artificially to allow the ewe's milk to be used for human consumption. They are also important in ensuring a more even supply of lambs to the market.

\section{MATERIAL AND METHODS}

\section{Experimental design}

The effects of three levels of gross energy $(\mathrm{GE})$ intake during the milk-feeding period (837-L, 1046-M and 1255-H kJ GE per $\mathrm{kg}^{0.75}$ per day) and two sexes (males and females) on growth rate, feed intake and feed utilization were studied using a randomized block experiment with a $3 \times 2$ factorial design in three periods of growth (milk-feeding, weaning and post-weaning).

\section{Experimental procedure}

Twenty-four newborn lambs of the Churra breed from multiple births were assigned randomly to treatment groups (4 lambs per group). During the first month of life the animals were housed in individual pens. They consumed only liquid food during this time (milk-feeding period). At 30 days of age the animals that had been assigned to each level of intake during the milk-feeding period were penned together to stimulate the consumption of solid food. Weaning was gradual and was carried out between days 30 to 37 (weaning period). Between days 38 and 77 solid food only was given (post-weaning period). 
The male lambs at each level of intake were confined to metabolism crates for the total collection of faeces at the third week after the start of the experiment. They were allowed 3 days to adjust to the crates and faeces output was measured and sampled for a further 4 days.

During the milk-feeding and post-weaning pcriods, all animals were weighed three times each week. During the weaning period the lambs were weighed daily.

In the first 2 days the lambs received colostrum ad libitum and from day 3 to 30 milk replacer. The liquid diet was given at three levels of intake $(H, M$ and $L)$ according to the experimental design. The milk replacer $[25 \%$ crude protein (CP) and 22.4 MJ GE kg dry matter ${ }^{-1}(\mathrm{DM})$ ] was prepared fresh at $190 \mathrm{~g} / \mathrm{kg}$ and was given at 9:00 and 17:00 h daily. The exact intakes were determined by weighing the bottles before and after drinking. A supply of clean drinking water was always available.

In the weaning period the lambs had free access to water, lucerne hay and a concentrate (barley $85 \%$, soyabean meal $13 \%$ and vitamin-mineral supplement $2 \%$ ). The milk replacer was given once in the morning at the maintenance level of feeding. The average energy intake from milk during the weaning period was $628 \mathrm{~kJ}$ GE per $\mathrm{kg}^{0.75}$ per day.

For the last experimental period (between 38 and 77 days of age) all lambs were offered the same lucerne hay and concentrate ad libitum.

Chemical components of the feeds and faeces were determined by standard methods (AOAC, 1980) and GE by adiabatic bomb calorimeter.

\section{Statistical analysis}

Data were subjected to variance and covariance analysis using LSMLMW (Harvey, 1970).

The models used were:

[1] $\mathrm{Yijk}=\mu+\mathrm{Ii}+\mathrm{Sj}+\varepsilon \mathrm{ijk}$

[2] $\mathrm{Yijk}=\mu+\mathrm{Ii}+\mathrm{Sj}+\mathrm{b} \mathrm{Xijk}+(\mathrm{bxI}) \mathrm{Xijk}+\varepsilon \mathrm{ijk}$

where:

Yijk - the individual observation

$\mu \quad-$ an clement common to all individuals

I - effect of level of intake during milk-feeding period

$S$ - effect of sex of lambs

Eijk - residual error

In the statistical model [2] the initial live weight in each period was used as a covariate (b) and the interaction of initial weight with the level of milk intake (bxI) was included. 


\section{RESULTS}

\section{Milk-feeding period}

All lambs remained in good health and completed the experiment. Lambs consumed all the milk substitute offered. Mean daily intakes of GE, together with the apparent digestibility coefficients of the diet at the levels of intake studied are presented in Table 1. GE intake $\left(\mathrm{kJ} / \mathrm{kg}^{0.75} / \mathrm{day}\right)$ was significantly different among levels of milk intake $(\mathrm{H}>\mathrm{M}>\mathrm{L}, \mathrm{P}<0.001)$. Dry matter $(\mathrm{DM})$, crude protein (CP) and GE digestibilities of the milk substitute were lower $(P<0.05)$ for the $H$ level of intake than the $L$ and $M$ levels.

Live body weight, growth rate and feed conversion ratio for the milk-feeding period are shown in Table 2. Birth weight, final weight and growth rates were estimated from the regression of live weight on time $(\mathrm{P}<0.001)$.

TABLE 1

Milk-feed period: daily gross energy intake (GEl) and digestibility of dry matter (DM), crude protein (CP) and energy (E)

\begin{tabular}{lcccc}
\hline & \multicolumn{3}{c}{ Level of milk intake } & \multirow{2}{*}{ SD' } \\
\cline { 2 - 4 } & $\mathrm{L}$ & $\mathrm{M}$ & $\mathrm{H}$ & \\
\hline GEI, KJ $/ \mathrm{kg}^{0.75}$ & $833.8^{\mathrm{a}}$ & $1035.1^{\mathrm{b}}$ & $1232.1^{\mathrm{c}}$ & 14.74 \\
Digestibility, $\%$ & & & & \\
DM & $93.0^{\mathrm{a}}$ & $93.1^{\mathrm{b}}$ & $89.4^{\mathrm{b}}$ & 0.58 \\
$\mathrm{CP}$ & $91.1^{\mathrm{a}}$ & $91.8^{\mathrm{a}}$ & $88.4^{\mathrm{b}}$ & 0.49 \\
$\mathrm{E}$ & $92.9^{\mathrm{a}}$ & $94.4^{\mathrm{a}}$ & $90.4^{\mathrm{b}}$ & 0.62 \\
\hline
\end{tabular}

$a, b, c$ mean values within rows followed by a different superscript differ significantly by LSD test $(\mathrm{P}<0.05)$

'standard deviation

TABLE 2

Milk-feed period: initial and final live body weight (LBW), live weight gain (LWG) and feed conversion (kg DM intake/kg LWG)

\begin{tabular}{|c|c|c|c|c|c|c|}
\hline & \multicolumn{3}{|c|}{ Level of milk intake } & \multicolumn{2}{|c|}{ Sex } & \multirow{2}{*}{$\mathrm{SD}^{\prime}$} \\
\hline & L & M & $\mathrm{H}$ & male & female & \\
\hline Initial LBW, kg & 2.94 & 3.06 & 2.73 & 2.99 & 2.83 & 0.606 \\
\hline LWG, g/day & $66.4^{4}$ & $109.3^{\mathrm{b}}$ & $127.4^{c}$ & 103.4 & 98.7 & 30.80 \\
\hline Final LBW, $\mathrm{kg}$ & $4.80^{3}$ & $6.12^{b}$ & $6.30^{\mathrm{b}}$ & 5.89 & 5.59 & 1.136 \\
\hline Feed conversion & 1.67 & 1.38 & 1.40 & 1.45 & 1.53 & 0.284 \\
\hline
\end{tabular}

a. b, $c$ mean values within rows followed by a different superscript differ significantly by LSD test $(\mathrm{P}<0.05)$

' standard deviation 
Mean birth weights of lambs in groups $\mathrm{L}, \mathrm{M}$ and $\mathrm{H}$ were similar $(2.94,3.06$ and $2.73 \mathrm{~kg}$ respectively, $\mathrm{P}>0.05$ ).

There were significant differences in live weight gain associated with nutritional level $(\mathrm{H}>\mathrm{M}>\mathrm{L}, \mathrm{P}<0.01)$. However, there were no differences between the final weights of lambs given the $\mathrm{H}$ and $\mathrm{M}$ levels of intake. This effect may be due to the slight difference in birth weight between the $\mathrm{H}$ and $\mathrm{M}$ lambs. This is supported by the fact that differences among the three levels of milk intake were statistically different $(\mathrm{P}<0.001)$ when initial live body weight was used as a covariate in statistical model [2], previously described.

There were no significant differences $(\mathrm{P}>0.05)$ between males and females in live weight and growth rate during the milk-feeding period (Table 2).

\section{Weaning period}

Table 3 records live body weight changes during the weaning period. Time from lowest weight, duration of the weaning check (time, measured in days after weaning, that each lamb took to regain its liveweight at weaning) and weight loss following weaning increased $(\mathrm{P}<0.05)$ with increasing level of milk intake during the pre-weaning period. Females had a higher weaning check than males $(\mathrm{P}<0.05)$.

TABLE 3

Weaning period: weight loss and duration of growth check

\begin{tabular}{lcccccccc}
\hline & \multicolumn{3}{c}{ Level of milk intake } & & \multicolumn{3}{c}{ Sex } & \multirow{2}{*}{ SD $^{1}$} \\
\cline { 2 - 3 } & $\mathrm{L}$ & $\mathrm{M}$ & $\mathrm{H}$ & & male & female & \\
\hline Time from lowest weight, days & 0.57 & 0.87 & 1.00 & & 0.60 & 1.00 & 0.167 \\
Duration of growth check, days & $1.43^{\mathrm{a}}$ & $2.12^{b}$ & $3.14^{\mathrm{c}}$ & & 1.70 & 2.67 & 0.435 \\
Weight loss, \% weaning wt & $1.81^{\mathrm{a}}$ & $2.24^{\mathrm{b}}$ & $3.37^{\mathrm{c}}$ & & 1.96 & 2.88 & 0.567 \\
Live weight gain, g/day & 143.2 & 139.5 & 148.3 & & 168.2 & 122.9 & 19.17 \\
\hline
\end{tabular}

$a, b, c$ mean values within rows followed by a different superscript differ significantly by LSD test $(\mathbf{P}<0.05)$

${ }^{1}$ standard deviation

\section{Post-weaning period}

Daily DM intake, feed conversion and roughage:concentrate ratio of the diet during the post-weaning period are given in Table 4 . Mean roughage dry matter intake was reduced from $40 \%$ for the first 2 weeks to $20 \%$ by the end of post-weaning period. 
TABLE 4

Post-weaning period: dry matter intake (DMI), roughage : concentrate ratio and feed conversion (kg $\mathrm{DMI} / \mathrm{kg}$ live weight gain)

\begin{tabular}{lccc}
\hline & \multicolumn{3}{c}{ Level of milk intake } \\
\cline { 2 - 4 } & $\mathrm{L}$ & $\mathrm{M}$ & $\mathrm{H}$ \\
\hline DMI, g/day & 495.9 & 458.5 & 529.3 \\
Roughage: concentrate ratio, $\%$ & $23.4: 76.6$ & $21.7: 78.3$ & $21.7: 78.3$ \\
Feed conversion & 2.81 & 2.65 & 3.45 \\
\hline
\end{tabular}

Live-weight gains for each pre-weaning level of milk intake and for each sex are shown in Table 5. There was no sex effect on the rate of live weight gain $(\mathrm{P}>0.05)$ during the post-weaning period (Table 5).

The initial live body weight in this period shows the differences in the growth rate found for the lambs with different pre-weaning levels of milk intake. Daily live weight gain $(\mathrm{g} / \mathrm{d})$ by lambs on treatment $\mathrm{H}$ was lower than for those on the $\mathrm{L}$ and $\mathrm{M}$ treatments, but this difference did not reach statistical significance $(\mathrm{P}>0.05)$. However, the post-weaning live weight gains corresponding to the three levels of intake studied were $27.1,31.1$ and $34.4 \mathrm{~g} / \mathrm{kg}^{0.75} /$ day for the levels $\mathrm{H}$, $\mathrm{M}$ and $\mathrm{L}$ treatments, respectively, and these values were statistically different $(\mathrm{P}<0.001)$. There were no statistically significant differences due to level of milk intake on the final live weight of the lambs.

TABLE 5

Post-weaning period:.initial and final live body weight (LBW) and live weight gain (LWG)

\begin{tabular}{|c|c|c|c|c|c|c|}
\hline & \multicolumn{3}{|c|}{ Level of milk intake } & \multicolumn{2}{|c|}{ Sex } & \multirow{2}{*}{$\mathrm{SD}^{\prime}$} \\
\hline & $\mathrm{L}$ & $M$ & $\mathrm{H}$ & male & female & \\
\hline Initial LW, kg & $5.17^{\mathrm{a}}$ & $6.27^{b}$ & $6.71^{b}$ & 6.46 & 5.63 & 1.232 \\
\hline Growth rate, g day ${ }^{\prime \prime}$ & 175.2 & 173.0 & 152.0 & 156.3 & 177.1 & 26.62 \\
\hline Final LW, $\mathrm{kg}$ & 12.53 & 13.53 & 13.09 & 13.03 & 13.07 & 1.616 \\
\hline
\end{tabular}

$a, b, c$ mean values within rows followed by a different superscript differ significantly by LSD test $(\mathrm{P}<0.05)$

${ }^{\prime}$ standard deviation

\section{DISCUSSION}

\section{Milk-feeding period}

During the milk-feeding period, the level of milk intake is a decisive factor in the growth of lambs. Restriction of the milk allowance reduced early growth and 
increased the dry matter, crude protcin and energy digestibilities of the milk which could be explained by the higher rate of passage of the digesta when the level of intake increases. This finding is similar to that of Peláez (1979) for commercial milk substitutes. With respect to the effect of the sex of the lambs our results are in close agreement with those of Sanz Arias et al. (1974) who found that in Churra lambs the differences between sexes did not become apparent until 13 weeks old as a consequence of late maturity of this breed of sheep.

The results during the milk feeding period are in agreement with those described for the same breed, though Sanz Arias et al. (1974) and Peláez (1979) found better results when the milk substitutes were formulated with either cow's or ewe's milk.

\section{Weaning period}

The weaning period is a critical phase in which the passage from the pre-ruminant to the ruminant is usually characterized by cessation of growth and weight loss. The weaning check was minimized by the gradual weaning and there was a negative correlation between the duration and severity of the growth check and the previous level of milk intake. This is in agreement with Large (1965), Davies and Owen (1967) and Walker and Hunt (1981) who observed that the intake of dry feed in this period was low when milk substitute was offered ad libitum.

Our results show a higher weaning check in females than in males (Table 3) which could be due to differences in body composition at weaning with a higher body fat content in females than males (Manso et al., 1994). In cattle, Wright et al. (1987) noted an increase in the effect restriction as the maturity of the animals increased.

\section{Post-weaning period}

The small number of animals per treatment and high variability could explain why differences in compensatory growth response were only observed when the growth rate was expressed as a proportion of metabolic weight.

The variability in the compensatory growth response suggests that several factors may be involved. The most important of these are the age at which the restriction is imposed, its severity and duration, the feed intake at realimentation and the feed and nutrient utilization (O'Donovan, 1984; Ryan, 1990; Iason et al., 1992; Manso et al., 1994).

Because the comparison between the different levels of nutritional restriction during the milk-feeding period is confounded by initial body weight, the results of the post-weaning growth rates were corrected by co-variance analysis using 
initial weight as a co-variate (Statistical model [2]). In this analysis growth rates during the post-weaning period were different $(\mathrm{P}<0.001)$ between previous levels of milk intake when expressed both in absolute $(\mathrm{g} / \mathrm{d})$ and relative terms $\left(\mathrm{g} / \mathrm{kg}^{0.75} / \mathrm{d}\right)$. This finding could arise more from differences in the feed conversion ratio, than differences in feed intake. It could also be a consequence of differences in maintenance requirements as a result of the previous levels of intake or a combination both of feed conversion efficiency and mainteinance needs (Ryan, 1990).

It can be concluded that the milk allowance for artificial-reared lambs can be reduccd without affecting their subsequent performance in terms of growth rate, feed intake and efficiency. Restriction during the milk feeding period also resulted in a lower weaning check. In practical terms, the linal decision is an economic one and must take into account the relative cost of liquid and solid feeds and the supply time of lambs to the market. The present study provides data for these economic calculations.

\section{REFERENCES}

AOAC, 1980. Official Methods of Analysis. 13th Edition. Association of Official Analytical Chemists. Washington, DC

Davies D.A.R., Owen J.B., 1967. The intensive rearing of lambs. 1. Some factors affecting performance in the liquid feeding period. Anim. Prod. 9, 501-508

Harvey W.R., 1970. listimation of variance and covariance components in the mixed model. Biometrics 26, 485-496

lason G.R., Mantecon A.R., Milne J.A., Sim D.A., Smith A.D.M., White L.R., 1992. The effect of pattern of food supply on performance, compensatory growth and carcass composition of Beulah and Welsh Mountain lambs. Anim. Prod. 54, 235-241

Large R.V., 1965. The artificial rearing of lambs. J. Agric. Sci., Camb. 65, 101-108

Iavin P., Mantecon A.R., Giraldez F.J., Diez P., 1994. Sheep production systems in the Central-North of Spain; current situation. In: A. Gibon, C. Flamant (Editors). The study of livestock farming systems in a research and development framework. Pudoc. Wageningen, pp. 202-206

Manso T., Mantecon A.R., Castro T., Lavin P., 1994. Body chemical composition of Churra lambs at $20 \mathrm{~kg}$ live weight: effect of level of milk intake and protein content in the post-weaning diet. Anim. Prod. 58, 481, Absir. 212

O'Donovan P.B., 1984. Compensatory gain in caltle and sheep. Nutr. Abstr. Rev., Ser. B, 54, 389-410

Owen J.B., Davies D.A.R., Ridgman W.J., 1969. The effects of quantity and distribution of liquid feed in lambs reared artificially. Anim. Prod. 11, 1-9

Peláez R., 1979. Digestibilidad, utilización de la energia y balance de nitrógeno en corderos de raza Churra, criados artificialmente a base de leche de oveja, leche de vaca y sustitutivos lacteos. PhD Thesis, Universidad de León 
Ryan W.J., 1990. Compensatory growth in cattle and sheep. Nutr. Abstr. and Rev., Ser. B 60, 653-664

Sanz Arias R., Ovejero F.J., Zorita E., 1974. Evolución del peso vivo de los corderos de raza Churra desde cl nacimicnto hasta las 20 semanas de edad. Anales Fac. Vel. de I.eón, 20, 101-109

Thonney M.L., Taylor St C.S., McClelland T.H., 1987. Breed and sex differences in equally mature sheep and goats. 1. Growth and food intake. Anim. Prod. 45, 239-260

Walker, D.M., I Hunt S.G., 1981. Early weaning of lambs: effect of various preweaning factors on voluntary food intake before and after weaning. Aust. J. Agric. Res. 32, 89-97

Wright I.A.. Russel A.J.F., Hunter E.A., 1987. The cffects of genotype and post-weaning nutrition on compensatory growth in cattle reared as singles or twins. Anim. Prod. 45, 423-432

\section{STRESZCZENIE}

\section{Wplyw ilości pobranej paszy w okresie mlecznym na wzrost jagniąt po odsadzeniu}

Dwadzicścia cztcry jagniçta rasy Churra, pochodzące z wielorakich urodzen, przydzielono do grup w układzie czynnikowym $3 \times 2$, « uwzględnieniem 3 poziomów pobrania mleka (837-L, 1046-M i $1255-\mathrm{H}$ kJ energii brutto na $\mathrm{kg}^{0.75} / \mathrm{dzien}$ ) oraz płci. Badano wplyw tych czynników na tempo wzrostu jagniąt w okresic mlecznym (0 do 36 dni), odsadzania ( 31 do 37 dni) i po odsadzeniu ( 38 do 77 dni). Przyrosty m.c. w okresie mlečnym różniły się istotnie $(\mathrm{P}<0,001)$ w zależności od ilości pobranego mleka (66, 109 i $127 \mathrm{~g} /$ dzień). Strawność suchej masy, białka ogólnego i energii brutto preparatu mleko-zastępczego była niższa $(\mathrm{P}<0,05) \mathrm{w}$ grupie $\mathrm{H}$ niż L i M. Straty m.c. w okrcsic odsadzania były tym mnicjsze niż jagnięta otrzymywały więcej mleka przed odsadzeniem. Przyrosty m.c. nie różniły się statystycznie istotnie pomiędzy tryc $/$ kami a maciorkami tak w okresie przed - jak i po odsadzeniu. Przyrosty dzienne jagniąt w okresie po odsadzeniu wynosily 34,$4 ; 31,1 \mathrm{i} 27,1 \mathrm{~g} / \mathrm{kg}^{0.73}$ odpowicdnio w grupach $\mathrm{L}, \mathrm{M}$ i $\mathrm{H}(\mathrm{P}<0,001)$. 